\title{
Nursing Students' Attitudes toward the Nursing Profession in western Turkey and Affecting Factors
}

\author{
Tulay Sagkal Midilli ${ }^{1}$, Nurcihan Durgun ${ }^{2}$ \\ ${ }^{I}$ (Corresponding Author/Nursing Department, Manisa Celal Bayar University Faculty of Health Sciences, \\ Assist. Prof., PhD. Turkey) \\ ${ }^{2}$ (Nurse, Erzurum, Turkey)
}

\begin{abstract}
Objective: The study was aimed at investigating nursing students' attitudes towards nursing profession, and factors affecting their attitudes.

Material and Methods:The study was carried out with $1^{\text {st }}, 2^{\text {nd }}, 3^{\text {rd }}$ and $4^{\text {th }}$ year nursing students of a health college in Turkey between May 21, 2012 and June 22, 2012. The population of the study included 292 students attending the health college. Because some students were absent from school at the time the study was conducted, some did not want to participate in the study, or some did not fill in the questionnaires completely, the study was conducted with 251 students. The participation rate was 86\%.Nursing Students' Identification Form and Attitude Scale toward Nursing Profession (ASNP) were used as data collection tools in the study.

Results: The mean age of the participants was $21.54 \pm 1.72$. Of them, $66.5 \%$ chose nursing of their own free will, $72.5 \%$ were satisfied with the nursing department, $53.8 \%$ considered the school's education satisfactory and $57.4 \%$ considered that the school administration and staff made satisfactory effort to gain students the sense of the profession. The mean score the participants obtained from the ASNP was 158.43. There was no statistically significant difference between their mean ASNP scores with regard to their age $(k W=0.710, P=$ 0.701). However, there were statistically significant differences between their mean ASNP scores with regard to their gender $(t=2.161, P=0.032)$, year at school $(t=6.613, P=0.001)$, whether they have chosen nursing of their own free will $(t=6.613, P=0.001)$ and whether they were satisfied with the nursing department $(10.629$, $P=0.001)$.

Conclusion: The results of this study demonstrated that nursing students had positive attitudes towards nursing. Of the participants who were female, who chose nursing of their own free will, who were satisfied with nursing, who considered the education given by the school as satisfactory and who considered that the school administration and staff made satisfactory effort to gain students the sense of the profession displayed more favorable attitudes towards nursing.
\end{abstract}

Keywords: Nursing, students, attitude, nursing profession

\section{Introduction}

Choosing a profession is a complex process affected by many factors varying from one country to another and from one culture to another. In addition to the properties of the profession and individual characteristics of the person, environmental conditions, political, economic, legal and systematic characteristics, luck, norms, and social values and attitudes affect one's choice of profession(Zencir and Eşer 2016). In choosing a profession, if a person is to adapt to the profession and to maintain a productive working life, he/she should have a positive opinion of and attitude towards the profession.

Having a positive opinion of and attitude towards the profession plays an important role not only in fulfilling individual success but also in the development of the profession (Eşer et al., 2008). Nursing schools need students who have qualifications appropriate to the nursing profession and display a positive attitude towards it. Therefore, to develop the nursing profession, nursing schools should educate students so that the students can have qualifications appropriate to the nursing profession and display a positive attitude towards it (Zencir and Eşer 2016).

Nursing students face many difficulties during their education process. Therefore, to improve the quality of nursing education by evaluating nursing curricula, to improve educational environments, to solve problems arising between educators and students, to increase students' satisfaction from education and profession, to make nursing a preferred profession by changing negative aspects of nursing, it is considered that it would be useful to encourage students to favor nursing and to determine their views on the institution they are studying in.

In Turkey, several studies have been conducted with nursing students attending various universities in different regions to determine their views on and perspectives towards nursing (Ünlü et al., 2008, Atasoy and Ermin, 2016, DeryaBeydag et al., 2008, Şirin et al. 2008, Özpancar et al. 2008), and their perception of nursing 
(Özmen and Çetinkaya 2016, Eşer et al. 2008, Karaöz 2002, Çıtlık et al. 2014). In addition, some studies have been carried out on why nursing is preferred and factors the affecting this preference (Kalkım et al. 2015, Demiray et al. 2013, İnce andKhorshid 2015, Andsoy et al. 2012, Önler and VarolSaraçoğlu 2010, Özdelikara et al. 2016). However, our literature review on studies investigating nursing students' attitudes towards the nursing profession suggests that such studies are very few (Zencir and Eşer 2016). On the other hand, in other countries, the number of studies conducted on nursing students' perceptions of nursing (Getu et al. 2015, Swarna 2015, Patidar et al. 2011, Oyedele Emmanuel et al. 2015, Tawfig Al Jarrah 2013, Tseng et al. 2013) and attitudes towards nursing (Miligi and Selim 2014, Mutair and Redwan 2016, Koushali et al. 2012, Gholap et al. 2014, Kaur et al. 2016) is higher. Therefore, we decided to perform a study to determine attitudes displayed by nursing students attending various universities both in Turkey and abroad towards nursing. Therefore, the present study was aimed at investigating nursing students' attitudes towards nursing profession, and factors affecting their attitudes.

\section{Study sample}

\section{Material And Method}

The study was carried out with $1^{\text {st }}, 2^{\text {nd }}, 3^{\text {rd }}$ and $4^{\text {th }}$ year nursing students of a health college in Turkey between May 21, 2012 and June 22, 2012. The population of the study included 292 students attending the health college. Because some students were absent from school at the time the study was conducted, some did not want to participate in the study, or some did not fill in the questionnaires completely, the study was conducted with 251 students. The participation rate was $86 \%$.

\section{Data collection}

Nursing Students' Identification Form and Attitude Scale toward Nursing Profession (ASNP) were used as data collection tools in the study.

Nursing Students' Identification Form developed by the researchers using the relevant literature consists of 7 items questioning sociodemographic characteristics such as age, gender, year at school, and attitudes towards nursing such as the place of nursing in the preference list (in Turkey, a student to start university makes a list of schools he/she wants to go by giving priority to the one (s) he/she prefers most), whether he/she has chosen nursing of his/her own free will, whether he/she is satisfied with the nursing department, whether he/she considers the education the school provides is satisfactory.

Attitude Scale toward Nursing Profession (ASNP): The scale was developed by Ipek, Coban, and Kasikci in 2010 in Turkish, and its validity and reliability was confirmed. It is a 5-point Likert-type scale and has 40 items. The Cronbach's alpha coefficient for the scale is 0.91 . The higher the score obtained from the scale is, the higher the positive attitude displayed towards the nursing profession is. The lowest and highest possible scores to be obtained from the scale are 40 and 200 respectively. The cut-off score of the scale is 80 . While those whose scores are above 80 displays a positive attitude, those whose scores are below 80 displays a positive attitude (Ipek, Coban and Kasikci 2011). To collect the study data, the survey method and the paper / pen technique were used.The data were collected in the classroom environment, before the class began or if there was no course in the room. The time required to fill out the questionnaire was between 10 and 12 minutes for each person.

\section{Data Analyses}

To analyze the data, the SPSS 16.00 package program, One-Way ANOVA, Kruskal Wallis and Independent ttests were used. $\mathrm{P}$ values below 0.05 were considered significant.

\section{Study's ethics}

The written permission to use the ASNP in the present study was obtained via electronic mail from the developers of the scale. The written permission was obtained from the institution where the study was to be conducted before the data collection phase. The students to participate in the study were informed about the purpose of the research, and their verbal consent indicating that they volunteered to participate in the study was obtained.

\section{Results}

The mean age of the participants was $21.54 \pm 1.72$ (min: 18 , max: 30$)$. Of them, $78.9 \%$ were in the 20 23 age group, $79.3 \%$ were female, $43 \%$ preferred nursing in the first place in the university entrance examination, $66.5 \%$ chose nursing of their own free will, $72.5 \%$ were satisfied with the nursing department, $53.8 \%$ considered the school's education satisfactory and $57.4 \%$ considered that the school administration and staff made satisfactory effort to gain students the sense of the profession (Table 1). 
The mean score the participants obtained from the ASNP was 158.43 (min: 97, max: 194) (Table 2). The participants' mean ASNP scores were analyzed in terms of some variables (Table 3). There was no statistically significant difference between their mean ASNP scores with regard to their age $(\mathrm{kW}=0.710, \mathrm{P}=$ 0.701). However, there were statistically significant differences between their mean ASNP scores with regard to their gender $(\mathrm{t}=2.161, \mathrm{P}=0.032)$, year at school $(\mathrm{t}=6.613, \mathrm{P}=0.001)$, whether they have chosen nursing of their own free will $(\mathrm{t}=6.613, \mathrm{P}=0.001)$ and whether they were satisfied with the nursing department $(10.629, \mathrm{P}=$ 0.001) (Table 3).

\section{Discussion}

While nearly half of the participants preferred the nursing department in the first place in the university entrance examination, more than half of them preferred the nursing department of their own free will and were pleased with the department. In several studies conducted in Turkey, half of the nursing students voluntarily selected the nursing profession (Zencir and Eşer 2016, Eşer et al. 2008, Demiray et al. 2013,Eşer et al., 2008) and nursing took the first three places among their preferences (Zencirand Eşer 2016, Demiray et al. 2013, Şirin et al. 2008, Eşer et al. 2008). While in Çınar et al.'s study (2011), 52.5\% of the participants were satisfied with nursing, in Yücel et al.'s study (2011), the number of the participants who favored the nursing profession was even higher $(84.2 \%-85.2 \%)$. In Turkey, the rate of the students who chose nursing of their own free will was low in the 1990s; however, it has increased in the 2000s (Zencir and Eşer (2016). Some studies conducted abroad, (MutairandRedwan 2016, Miligiand Selim 2014) yielded results similar to those of the present study indicating that they chose the profession by their own preference. However, there are other studies indicating that the students did not prefer nursing in the first place (Lai et al. 2008) or that they would never prefer it (Kandari et al. 2005, Mooney 2008). This is probably due to cultural, social and political differences or due to the characteristics of the study populations.

Half of the students participating in the present study were satisfied with the education given in the school they attended and they considered that the school administration and staff made satisfactory effort to gain students the sense of the profession. These results suggest thatthe school administration and staff's effort to gain students the sense of the profession was not as much as it should be.

Nursing education includes theoretical and practical learning and teaching experiences. The aim of nursing education is to provide professional nursing skills to students, to prepare them in accordance with the requirements of their future professional lives, to equip them with qualifications to deal with current health problems and to raise their awareness of their duties and responsibilities to their country (Ünlü et al., 2008).During their education process, nursing students experience several problems. For instance, they may not enjoy the profession, time allocated to the learning of theoretical data is very short, they are responsible for learning all this intensive data, they should stay in the hospital or a foreign environment during clinical practices, they are exposed to stressors created by the clinical environment and team, they may have problems with the teaching staff, and they may be incompetent during practices or while giving healthcare (Ünlü et al., 2008). Therefore, if nursing schools are to provide students with the required professional qualifications, they should review their curriculum to increase the quality of nursing education, to make educational environments more qualified, to increase students' satisfaction from education and profession, to change the negative aspects of nursing and to make nursing a favored profession.

The participants of the present study had positive attitudes towards nursing. The review of studies conducted both in Turkey and abroad revealed that their results were in parallel with those of the present study (Tawash and Cowman 2015, Zencir and Eşer 2016, Kaur et al. 2016, Koushali et al. 2012, Mutair and Redwan 2016, Miligi and Selim 2014). These results indicate that nursing students displayed a positive attitude towards their profession despite the differences in the students who were educated in different universities in different countries and in their viewpoints of the social professional image. This positive attitude is attributed to disappearance of the ambiguity experienced by the choice of the profession and to the establishment of the social support between the student, the profession and the family (Zencir and Eşer 2016, Iş1k 2013).

\section{Affecting Factors}

In the present study, there was no difference between the participants from different age groups in terms of their attitudes towards nursing; however, they displayed less favorable attitudes as their age increased. The comparison of the participants' attitudes towards the nursing profession in terms of their year at school indicated differences between them, in particular between the $2^{\text {nd }}-$ and $4^{\text {th }}$-year students. On the other hand, according to the mean ASNP scores, the highest difference was between the $4^{\text {th }}$ - and $1^{\text {st }}$-year students. While in Kaur et al.'s study (2016), the first-year nursing students had a favorable attitude towards nursing, in Miligi and Selim's study (2014), there was no difference between the students in different classes. Grainer and Bolan (2006) stated that the first- and fourth-year student nurses displayed a positive image of nursing because the fourth-year students had more knowledge about the role of nurses they had a realistic perception of many roles 
and opportunities in nursing. Students who start nursing education with prejudiced views held by the society and without knowing profession well are not expected to have a favorable view of the profession at the start of their school life. Students' perceptions of the profession my change favorably or unfavorably after the theoretical and practical training they have received (Eşer et al. 2008). While the first-year students are expected to have a negative attitude compared to the third- and fourth-year students, in other words, they are expected to display a more favorable attitude as their years at school increase, this was not the case in the present study; there was a fluctuation between the students' attitudes towards nursing with regard to their year at school. This can be explained by the fact that students are more ambitious and have positive expectations when they start school and in the first years of their education process, but that they lose their ambition and have negative expectations as their years at school increase due to the difficulties of the profession they come across over time, the quality of the education given by the school and the role model of the nursing educators. In this transition period, it is important to give students courses on professional entrepreneurship and to guide them appropriately and reliably in line with their goals (Kalkım et al. 2015).

Female students displayed a more positive attitude towards the nursing profession than did male students. While Kalkım et al. (2015) stated that female gender was a factor affecting career choice, Mutair and Redwan (2016) stated that female students' attitudes towards nursing were more favorable. In their review of studies conducted in Turkey, Kalkım et al. (2015) report that until 2007, nursing was considered a women's profession and the majority of patients perceived nursing as a profession unique to women. They also report that in recent years, this view has changed and nursing is now perceived as a profession both for men and for women and that in nursing practices not gender but success is of great importance. This is probably due to the fact that nursing was a profession carried out only by women until 2007 in Turkey. In fact, nursing is a profession aiming to protect and improve the health of the individual, the family and the society, to treat illnesses, to rehabilitate the person and to improve the quality of life, and it can be carried out by both genders without gender discrimination. (Terzioğlu and Taşkın 2008),

Similar to the present study, in two studies one of which was conducted in Turkey (Zencir and Eşer 2016) and the other of which was conducted in Hong Kong (Law and Arthur 2003), students who chose nursing of their own free will displayed more favorable attitudes towards nursing. In Kalkım et al.'s study (2015), the factor affecting the nursing students' choosing nursing as a profession was the fact that they liked nursing. The decision to choose nursing as a profession, to stay in this profession and to progress in the career is probably the consequence of nurses' perception of the profession (Emeghebo 2012). Choosing the nursing willingly ensures that individuals carry out their profession willingly, get satisfied with nursing, become the members of nursing fulfilling the requirements of nursing, and provide quality health care. If nursing is to advance and if its status is to be raised in Turkey, it should be implemented and achieved precisely. In order for this goal to be achieved, new students who will join the profession should love their profession, they should see the future of their profession and thus their future promising and they should display positive attitudes towards their profession (Kalkım et al. 2015).

\section{Conclusion}

The results of this present study demonstrated that nursing students had positive attitudes towards nursing. In the present study, of the participants, those who were female, who chose nursing of their own free will, who were satisfied with nursing, who considered the education given by the school as satisfactory and who considered that the school administration and staff made satisfactory effort to gain students the sense of the profession displayed more favorable attitudes towards nursing. It is recommended that future studies should be conducted with larger samples from different universities in different countries to investigate and compare nursing students' attitudes towards nursing.

\section{Acknowledgments}

The authors would like to thank all nursing students who participated in this study.

Declaration of interest: None.

Grant Support \& Financial Disclosures: None.

\section{References}

[1]. Tawash E, Cowman S. Bahraininursingstudents' attitudes: fromstudenttonurse-A longitudinalresearchstudy. Journal of NursingEducationandPractice, 2015; 5(12): 79-87.

[2]. Emeghebo L. Theimage of nursing as perceivedbynurses. NurseEducationToday. 2012; 32: e49-e53. PMid:22079480http://dx.doi.org/10.1016/j.nedt.2011.10.015.

[3]. Grainer P, Bolan C. Perceptions of nursing as a careerchoice of students in thebaccalaureatenursing program. NurseEducationToday. 2006; 26: 38-44.

[4]. Ünlü S, Özgür G, BabacanGümüş A. School of nursing students' views and expectations related to nursing profession and education. EgeÜniversitesiHemşirelikYüksekokuluDergisi, 2008; 24(1):43-56. 
[5]. Eşer İ, Khorshid L, Denat Y. The effect of the first clinical practice to the perception of Nursing. EgeÜniversitesiHemșirelikYüksekokuluDergisi, 2008; 24(1):15-26.

[6]. Demiray A, Bayraktar D, Khorshid L. Thereasonsforchoosingnursingprofessionandexperiencedproblems of malenursingstudents. International Journal of Human Sciences, 2013;10(1):1440-1455.

[7]. İnce S, Khorshid L. Determination of factorsaffectingcareerchoices of nursingstudents. AnadoluHemşirelikveSağlıkBilimleriDergisi, 2015;18(3): 163-171.

[8]. Andsoy II, Güngör T, Bayburtluoğlu T. Karabuk university health school students' thoughts about the future of their profession and the causes of preferring nursing. Balıkesir Health Sciences Journal, 2012; 1(1): 124-130.

[9]. Önler E, VarolSaraçoğlu G. ValidityandReliability of theTurkishVersion of the HMSÖ. DEUHYO ED 2010; 3(2):78-85.

[10]. Özdelikara A, Ağaçdiken S, Aydın E. CareerChoices of NursingStudentsandInfluencingFactors.ACU SağlıBilDerg 2016; 6(2):83 88 .

[11]. Karaöz S. Changes in students' perceptions of nursing profession during nursing education: the role of introduction to nursing courses on this change. C. Ü. HemşirelikYüksekOkuluDergisi, 2002, 6 (2): 10-20.

[12]. IpekCoban G, Kasikci M. Development of theAttitudeScaleforNursingProfession. International Journal of NursingPractice 2011; 17: 518-524.

[13]. Zencir G, Eşer I. NursingStudents' AttitudestowardstheNursingProfession, NursingPreferred with theRelationshipbetween: Example of Turkey. DEUHFED 2016; 9(2), 30-37.

[14]. ÇıtlıkSarıtaş S, Derin N, Sarıtaş S. TheEffect of Professional Image Perception on Intention of StayingProfession at NursingStudents. İnönüÜniversitesiSağlıkilimleriDergisi 2014; 3(1): 29-32.

[15]. Atasoy I, Ermin C. An Investigation on the Professional Perspectives of theNursingandMidwiferyStudents. Journal of DuzceUniversityHealthSciencesInstitute / J DU HealthSciInst. 2016; 6(2): 83-91.

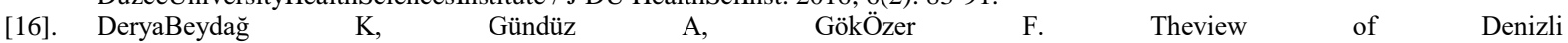
HealthCollegestudentsabouttheireducationsandtheirprofessionalexpectations. Pamukkale MedicalJournal, 2008;1(3):137-142.

[17]. Şirin A, Öztürk R, Bezci G, Çakar G, Çoban A. NursingStudents' OpinionsRelatedtoSelectionandApplication of Profession. Dirim T1p Gazetesi 2008: sayı: 83: 69-75.

[18]. Özpancar N, Aydın N, Akansel N. Determination of BeginingNursingStudents' PerceptionsAboutNursingProfession. C.U. HemsirelikYuksekokuluDergisi 2008, 12(3): 9-17.

[19]. Getu MA, Gebru AA, Semaw BE. Assessment of Nurse'sPerceptiontowardsTheirProfessionandFactorsAffectingIt in DebreBerhan TownGovernmentalHealthInstitution, DebreBerhan, Ethiopia. AmericanJournal of NursingScience, 2015; 4(6): $297-304$.

[20]. Swarna S. NursingStudentsPerceptiontowardsProfessionandFutureIntentions. IOSR Journal of NursingandHealthScience (IOSRJNHS), 2015; 4(5):30-34.

[21]. Miligi E, Selim A. SaudiNursingStudents' AttitudestowardstheNursingProfession. EuropeanJournal of Business and Management, 2014; 6(29):197-208.

[22]. Mutair AA, Redwan F. UndergraduateSaudiNursingStudentsAttitudestowardsNursingProfession. J NursCare 2016; 5(1):1-5.

[23]. Patidar AB, Kaur J, Sharma SK, Sharma N. Futurenurses' perceptiontowardsprofessionandcarrierplans: A crosssectionalsurvey in statePunjab. NursingandMidwiferyResearchJournal, 2011; 7(4): 175-185.

[24]. OyedeleEmmanuel A.,Emmanuel Andy, Gaji Luka D., GoshitJidauna D., Louis Okonkwo I. Perception of UndergraduateNursingStudentsaboutNursingProfession: A Study of University of Jos, Nigeria. International Journal of NursingandHealthScience. 2015; 2(5): 60-63.

[25]. Tawfig Al Jarrah IA. Associatenursingstudents' perceptionstowardnursingprofession in Jordan. EuropeanScientificJournalFebruary 2013; 9(6): 147-166.

[26]. Koushali AN, Hajiamini Z, Ebadi A. Comparison of nursingstudents' andclinicalnurses' attitudetowardthenursingprofession. IranianJournal of NursingandMidwiferyResearch. 2012; 17(5): 375-380.

[27]. Gholap MC, Mohite Chendake MB. StudytoAssessthe andAttitudetowardsNursingProfessionamongCollegeTeachers in Karad. International Journal of ScienceandResearch (IJSR), 2014; 3(4): 891-894.

[28]. Kaur L, Kanika, Kumar A. Assesstheattitude of nursingstudentstowardsnursingprofession. International Journal of AppliedResearch 2016; 2(6): 738-741.

[29]. Tseng HC, Wang HH, Weng WC. Nursingstudents' perceptionstowardthenursingprofessionfromclinicalpracticum in a baccalaureatenursingprogram: Aqualitativestudy. KaohsiungJournal of MedicalSciences, 2013; 29:161-168.

[30]. Işı1k, E. Meslekisonuçbeklentisininyordayıcılarılarakalgılanansosyaldestekvedenetimodağı, KuramveUygulamadaEğitimBilimleri. $2013 ; 13(3): 1419-1430$

[31]. Lai HL, Lin YP, Chang HK, Chen CJ, Peng TC,Chang FM. Is NursingProfessionmyfirstchoice? A followupsurvey in preregistrationstudentnurses. NurseEducationToday, 2008; 28(6):768-776.

[32]. Kandari FH,Lew I. Kuwaitihighschoolstudents' perceptions of nursing as a profession: implicationfornursingeducationandpractice. J NursEduc. 2005; 44(12): 533-540.

[33]. Mooney M,Glacken M, O’Brien, F. Choosingnursing as a career: A qualitativestudy. NurseEducationToday.2008; 28(3):385-392.

[34]. Law W, Arthur D. Whatfactorsinfluence Hong Kong schoolstudents in theirchoice of a careering nursing? International Journalof NursingStudies 2003; 40(1):23-32.

[35]. Yücel SÇ, Güler EK, Eşer İ, Khorshid L. İkiFarklıEğitimSistemi İle ÖğrenimGörenHemşirelik Son SınıfÖğrencilerininHemşirelikMesleğiniAlgılamaDurumlarınınKarşılaştırılması.EgeÜniversitesiHemşirelikYüksekOkuluDergisi, 2011, 27: 1-8.

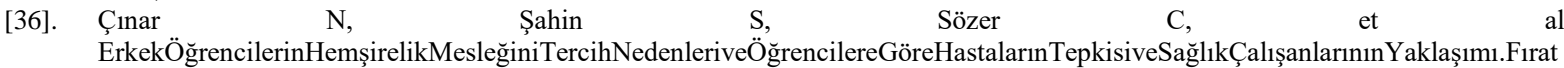
SağlıkHizmetleriDergisi, 2011; 6:15-25.

[37]. Terzioğlu F, Taşkın L. KadınınToplumsalCinsiyetRolününLiderlikDavranışlarınaveHemşirelikMesleğineYansımaları. CumhuriyetÜniversitesiHemşirelikYüksekokuluDergisi, 2008;12:62-67.

[38]. Kalkım A, SağkalMidilli T, Uğurlu E, Gülcan E.Hemşireliköğrencilerininmeslekseçimiveetkileyen değişkenlerin incelenmesi. Uluslararası Hakemli Hemşirelik Araştırmaları Dergisi. 2015; 4:41-60. 
Table 1. Characteristics of Nursing Students $(n=251)$

\begin{tabular}{|c|c|c|}
\hline \begin{tabular}{|l|} 
Characteristics \\
\end{tabular} & $\overline{\mathrm{n}}$ & $\%$ \\
\hline \begin{tabular}{|l} 
Age groups \\
$18-19$ \\
$20-23$ \\
$24-30$ \\
$\quad X=21.54 \pm 1.72$ \\
\end{tabular} & $\begin{array}{c}26 \\
198 \\
27\end{array}$ & $\begin{array}{l}10.4 \\
78.9 \\
10.8\end{array}$ \\
\hline \begin{tabular}{|l|} 
Sex \\
Female \\
Male \\
\end{tabular} & $\begin{array}{c}199 \\
52 \\
\end{array}$ & $\begin{array}{r}79.3 \\
20.7 \\
\end{array}$ \\
\hline $\begin{array}{l}\text { Year at school } \\
1^{\text {st }} \\
2^{\text {nd }} \\
3^{\text {rd }} \\
4^{\text {th }} \\
\end{array}$ & $\begin{array}{l}41 \\
95 \\
63 \\
52\end{array}$ & $\begin{array}{l}16.3 \\
37.8 \\
25.2 \\
20.7\end{array}$ \\
\hline $\begin{array}{l}\text { Preference order of nursing in university e } \\
\text { examination } \\
1^{1 \mathrm{t}} \\
2^{\text {nd }} \text { and above }\end{array}$ & $\begin{array}{l}108 \\
143\end{array}$ & $\begin{array}{l}43.0 \\
57.0\end{array}$ \\
\hline $\begin{array}{l}\text { Be self-preference of nursing } \\
\text { Yes } \\
\text { No }\end{array}$ & $\begin{array}{c}167 \\
84\end{array}$ & $\begin{array}{l}66.5 \\
33.5\end{array}$ \\
\hline $\begin{array}{l}\text { Beingsatisfiedwiththenursingdepartment } \\
\text { Satisfied } \\
\text { Not satisfied }\end{array}$ & $\begin{array}{c}182 \\
69\end{array}$ & $\begin{array}{l}72.5 \\
27.5\end{array}$ \\
\hline $\begin{array}{l}\text { Being satisfied with the school's education } \\
\text { Yes } \\
\text { No }\end{array}$ & $\begin{array}{l}135 \\
116\end{array}$ & $\begin{array}{l}53.8 \\
46.2\end{array}$ \\
\hline $\begin{array}{l}\text { Attitude of the school to gain profession } \\
\text { Enough } \\
\text { Not enough }\end{array}$ & $\begin{array}{l}144 \\
107\end{array}$ & $\begin{array}{l}57.4 \\
42.6\end{array}$ \\
\hline
\end{tabular}

Table

Students' Mean

\begin{tabular}{|l|c|c|c|}
\hline & $\mathbf{N}$ & Min-Max & $\mathbf{X} \pm$ sd \\
\hline ASNP & 251 & $97-194$ & $158.43 \pm 19.98$ \\
\hline
\end{tabular}

2.Nursing ASNP Scores

Table 3. Mean ASNP Scores According to Some Variablesof Nursing Students

\begin{tabular}{|l|c|c|c|}
\hline Variables & $\mathbf{n}$ & $\mathbf{X} \pm \mathbf{s d}$ & Test \\
\hline Age groups & & & $161.00 \pm 19.67$ \\
$18-19$ & 198 & $158.24 \pm 20.43$ & $\mathrm{~kW}=0.710$ \\
$20-23$ & 27 & $157.25 \pm 17.16$ & $\mathrm{P}=0.701$ \\
$24-30$ & & & \\
\hline Sex & 199 & $159.81 \pm 19.44$ & $\mathrm{t}=2.161$ \\
Female & 52 & $153.13 \pm 21.29$ & $\mathrm{P}=0.032^{*}$ \\
Male & & & \\
\hline Year at school & 41 & $161.07 \pm 20.86$ & $\mathrm{~F}=2.786$ \\
$1^{\text {st }}$ & 95 & $153.95 \pm 22.16$ & $\mathrm{P}=0.041^{*}$ \\
$2^{\text {nd }}$ & 63 & $159.98 \pm 19.72$ & $2<4$ \\
$3^{\text {rd }}$ & 52 & $162.63 \pm 13.14$ & $\mathrm{t}=6.613$ \\
$4^{\text {th }}$ & & & $\mathrm{P}=0.001^{*}$ \\
\hline Be self-preference of nursing & 167 & $163.89 \pm 16.78$ & $\mathrm{t}=10.629$ \\
Yes & 84 & $147.56 \pm 21.43$ & $\mathrm{P}=0.001^{*}$ \\
\hline No & 182 & $165.29 \pm 14.50$ & \\
\hline Beingsatisfiedwiththenursingdepartment & 69 & $140.33 \pm 21.20$ & \\
\hline Satisfied & & & \\
Not satisfied & & & \\
\hline
\end{tabular}

$* \mathrm{p}<0.05$ 